\title{
海難に関係する要因の関連について
}

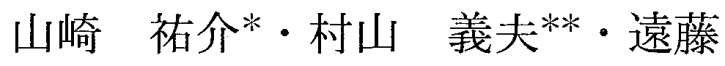

\section{A Pilot Study for the Influence on Links of Marine Casualties' Factors}

真*

\author{
Yusuke YAMAZAKI, Yoshio MURAYAMA and Makoto ENDO
}

\begin{abstract}
A result of the accident investigation should be needed to get clear causes for the prevention measures. Many factors are related mutually in marine casualties. Multivariable Contingency Analysis is the most fundamental method to examine the participation of other factors in the connection that factors are mutual.

Using the data made by Marine Disaster Agency, authors made analysis by the method and could make sure of that the method is useful for the investigation of marine casualties, and got a following result.

The cognition error has the relation to the factors as "single watch", "auto-pilot", and "night time".

This result stayed with having made well-known facts clear quantitatively, because investigation items of data were short. It is not easy to get detailed data that shows the truth of the casualty. And, authors consider that it is effective to analyze the incident data by this method.
\end{abstract}

\section{1. 序論}

海難の多くが人的要因によって起こっていることが指摘されている(1)。最近では、海難における人的要因 を詳細に検討するための調查方法のあり方が論議され、調査項目の標準化等が検討されている ${ }^{(2)}$ 。れらの 調查結果を、海難防止対策の対象、対策の方法㧍よびその効果を知るうえで活かすには、調查データを分 析する方法を発展させる必要がある。

一般に事故は、きっかけとなる直接要因、その背後に直接要因を成り立たせた背景要因が存在し、それ らは複雑に関連している(3)。海難についても同様であり、種々の条件が関係し合って起こる。そのような海 難の防止には、状沉に特有な要因相互の関係を絶つことが防止対策になると考えられる。その場合、海難 調査データの統計解析によってそれを知ることは有意義である。

これまでの海難調查結果は、基本的統計と単純クロス集計(零次クロス表集計)によって、海難の起こり やすい状況を示すにとどまっている(4)。例えば、操船者の年齢と船種、自動操舵使用と船種の関係などが個 別に示されているが、これらの関係は互いに無関係ではない可能性がある。そのようなとき、クロスして 示された二つの条件の関連には、別の重要な条件が関与していることもあり、その関連性は見かけ上の関 係であったり、さらにはあまり重要でない関係の場合がある(5)。

ある二つの条件の関連に別の条件の関与を吟味する最も基本的な統計分析方法は多重分割表分析であ る。これは一次または高次のクロス集計表を利用する分析であり、海難の発生に至る二つの条件 (以下、要 因)の関連を、別のある要因の存在を無視したときと、その要因を考慮して条件を統一したとき(統計的に



**正会員 財団法人 海上労働科学研究所（テ $102-0083$ 東京都千代田区桠町4-5海事センタービル） 
は統制という)、例えばレーダの使用と衝突の相関を、レーダ使用未熟群と熟練群に分けたときのその相関 の関係をみることによって、レーダ使用と衝突との関係における熟練度の寄与が明らかになる。

最近、筆者らは、海難防止の多角的取り組みの重要性を認識し、海難審判庁の資料汃ら海難の人的、物 的、環境、管理的な側面の全般に亘って海難要因を抽出した。各要因は海難への影響程度が不明なデータ である場合が多いので、尺度や順序などの量的データで表すことが難しいことから、データ内容を顕著に 区分できる二つのカテゴリーに分類した。そして、海難状況を、海難直前まで危険の認知が無かった場合 と、危険の認知が有った場合に分け、危険の認知が有った場合には、余裕ある視認距離であった場合とそ らでない場合の三つに分類した。そして、単純クロス集計(零次クロス表)によって、危険の認知状況、余 裕の有る状況、及び余裕の無い状況と各要因との関連性を求め、さらに、各海難状況別に行った一次ク口 ス集計によって、状況に特有な要因相互関係を抽出した。その結果、危険の認知が無い場合で10対、危険 認知吕有って余裕ある状況で 9 対、余裕が無い状況で 4 対の重要な要因関係を指摘した ${ }^{(6)}$ (以下、前報)。こ のうち、4 対は要因関連の解釈とオッズ比の大きさから注目すべきものであることが明らかであったが、 抽出された海難状況に特異な要因関連のうち 5 割は、状況に依存した関連、属性に必然な関連、他の関わ りが大きいか、見かけ上の関連などが示唆され、別の要因との関わりが分からなけれげ解釈不能であった。

本報告では、前報の分析の中で明らかになった主要な要因の関係を抽出し、その関係に関わる第三の要 因の関与を分析する方法を検討した。また、海難の重要な側面である危険の認知ミスと要因との関係に関 わる要因について注目し、危険の認知と要因の関連、危険の認知々関連する要因と他の要因の関係につい て、危険の認知ミスをもたらす背景要因の相互関係を整理することとした。

\section{2. 調査方法}

\section{1 多重クロス表による要因関連分析の方法}

一般に二つの变数が量的变数の場合にはその関連は、ピアソンの相関係数で判断される。質的変数であ っても 2 值変数の $2 \times 2$ 表の場合にはこれが可能である。ある結果 $\mathrm{A}$ の原因となる条件が B しか考えられ ないとすれば、単純なクロス集計による相関で条件としてBの影響程度を知ることができる。しかしこの ようなことはまれで、別の条件 C も影響することが多い。条件 C の影響を分析する手法が多重クロス分析 である。

海難の結果 $\mathrm{A}$ とそれに関わる要因 B の関係が要因Cのカテゴリーで分割しその影響を同じに保った場合 に $\mathrm{A}$ - Bが無関係になり、条件 Cのカテゴリーの違いが $\mathrm{A}$ - B 関係をもたらしていた場合、それは見かけ 上の関係で疑似関係である。要因 $\mathrm{C}$ のつつのテゴリーで分けた場合の $\mathrm{A}$ - B 間にある程度の相関がある 場合には、要因 $\mathrm{C}$ は $\mathrm{A}-\mathrm{B}$ 関係に部分的に関わっており、部分的効果があるとされる。要因 $\mathrm{C}$ のるカテ ゴリーで $\mathrm{A}$ - B の相関が大きくなり、他方が小さくなるとき、交互作用効果とされる。要因 $\mathrm{C} の$ 各カテゴ リ一群がともに要因 $\mathrm{C}$ 無視した関係と同じ程度で $\mathrm{A}$ - B 間に相関があるとき、要因 $\mathrm{C}$ はその関係に関わ りがない。以上の関係を吟味して、要因と結果の真の関連性を探ることができる。

本論では、主要な要因関連の零次クロス集計において有意な関連を持つものについて、別の要因で統制 した一次クロス表を求め、その相関係数のレベルから以下の掠むむねの基準に基づいて第三要因の効果を 分類した。

（1）第三の要因が完全な効果をもつ場合

第三要因のカテゴリ一別に分けて山来る二つの下位表の相関がそれぞれ 0 に近い場合、注目した二要因 間の関連は、第三要因によって左右される疑似関係とみなす。その基準は、それぞれの下位表の相関係数 (以下R'、 $\mathrm{R}^{\prime \prime}$ )が0.1末満とした。

(2) 第三の要因が部分的効果を持つ場合

二つの下位表で零次のクロス表の相関 (以下、R)より弱い相関がともにみられる場合、第三要因は部分的 な効果作用がある。その基準は、 $\mathrm{R}^{\prime} 、 \mathrm{R}^{\prime \prime}$ はともに $\mathrm{R} よ り さ さ 、 ~ R と \mathrm{R}^{\prime}$ 及びR" の差がともに0.05以上0.1 未満、または一方の差が0.1以上で他方の差が0.05未満とした。

（3）第三の要因が交互的作用をする場合

二つの下位表の相関の一つがRより小さく他方が大きい場合、第三要因はその関係に一方が大きく影響 
する交互作用効果がある。その基準は、 $\mathrm{R}^{\prime} ま た は \mathrm{R}^{\prime \prime か ゙ ~} \mathrm{R} よ り 大 き く \mathrm{R}^{\prime} 、 \mathrm{R}^{\prime \prime}$ 両者の差が0.1以上の場合とし た。

（4）第三の要因が效果を及ぼさない場合

二つの下位表の相関が零次のクロス表とほぼ同じ場合、第三の要因はその関係に関わりがない。その基 準は、RとR'及びR”の差が0.05未満とした。

これらの分類基準は今回の報告における目安であり、本論で扱った一次クロス集計におけるピアソンの カイ 2 乗漸近有意両側確率值が 0.05 の場合のピアソンの相関係数Rは 0.15 周辺であったことから、以上の ようにおおまかにその目安として設定した。

具体的な統制効果は、この基準以外にも図 2 によめて示す、三重クロス表の内容を加味して判断した。

2.2 分析データ

分析資料は前報の海難調査データである。これは、海難審判庁が統計資料のために作成したもので、調 查項目は99項目であった。その中から24項目を抽出しそのうちの20項目を二つのカテゴリーに分類した。 表 1 はそのアイテムとカテゴリー分類の一覧である。要因の関連性は、順序関係や程度の尺度が不明な質 的変数であっても、このように、二つのカテゴリーに分類し、 $2 \times 2$ 表の相関係数によって関連性の程度 を表すことができる。そして、商船の操船作業に限定するために、分析の対象を 100 総卜ン以上の貨物船・ タンカーの船舶間衝突、乗揚げ及び、単衝突(岸壁、灯浮標等の施設への衝突・接触) とした。また、海難 状況を、危険の認知が無かった場合と危険の認知が有った場合に以下の基準によって分類した。

(1)危険の認知無し(以下、危険認知無)

・(乗揚げ または 単衝突)かつ(避航動作無しまたは直前速力が10ノット以上)

・(船舶間衝突)かつ(初認距離が500米未満かつ初認時期が直前〜30秒前)かつ(避航動作無しまたは直前 速力が10ノット以上)

(2)危険の認知有り (以下、危険認知有)

・危険認知無以外の場合

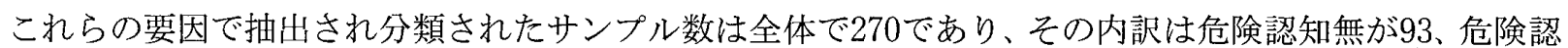
知有が177であうた。

表 1 アイテム・カテゴリ一分類

\begin{tabular}{|c|c|c|}
\hline \multirow{5}{*}{$\begin{array}{l}\text { 分類 } \\
\text { 海難 } \\
\text { 汱 }\end{array}$} & アイテム & カテコリー \\
\hline & 海難種類 & 船舶間衝㚙 乗揚げ 衝突(単) その他 \\
\hline & 初認時機 & 直前 30 秒前 $1 \sim 3$ 分前 3 分以上前 \\
\hline & 初認距離 & 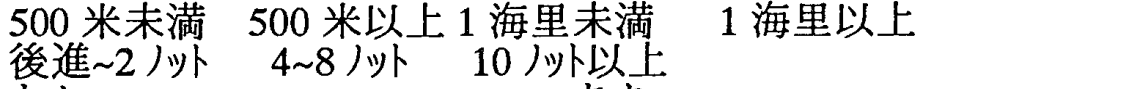 \\
\hline & 避航動作 & $\begin{array}{ll}\text { なし } & \text { あ } \\
\text { 危険認知無 } & \text { 危険認知有 }\end{array}$ \\
\hline \multicolumn{3}{|r|}{6 人地 } \\
\hline & 在橋人数 & 複数当直） \\
\hline \multirow{3}{*}{ 物的要因 } & 船簌 & 貨物・油蒵船 \\
\hline & 総以数 & $\begin{array}{l}100 \text { ト以上 } 700 \text { ト未満（小型） } 700 \text { 以以上（大型） } \\
\text { なと・不使用 }\end{array}$ \\
\hline & 自動操舵 & なし·不使用 \\
\hline 環境要闻 & 時間带 & 葆 $(20 \sim 24 、 00 \approx 08 \text { 時 })^{-}$ \\
\hline & 永域 & $\begin{array}{l}\text { 港・水道・海峡（狭い） } \\
\text { 無 }\end{array}$ \\
\hline & 呴云候 & 集・霧等 \\
\hline & 視等 & 1 扣末澫 \\
\hline 人的要因 & 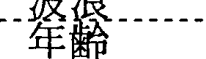 & 50 才以上(高年) \\
\hline & 職種 & 船長 \\
\hline & 免状 & 海技士（航海）免状受有以外 \\
\hline & $\begin{array}{l}\text { 職務経験 } \\
\text { 海上経験 }\end{array}$ &  \\
\hline
\end{tabular}




\section{3 分析の手続き}

要因の関連性を吟味するステップは以下の三段階となっている。

(1) 危険認知ミスに関連する要因の抽出

単純クロス集計の相関行列から得た前報における要因関連図およびRの大きさ、危険認知ミスと直接関 連する要因 (以下、直接要因という)、さらに危険認知に関して重要かどうかの判断によって危険認知の関 連要因図を求める。

(2) 危険認知と直接要因に関係する他の直接要因

危険認知の有無と要因との関係に別の要因がいかなる関係にあるかを分析する手順である。一次クロス 集計によって、別の要因で二つの下位表に分割して、各表の相関を前述した関係分類等に当てはめる。

(3) 直接要因間に関係する別の徝接要因

要因と要因の関係に別の要因がいかなる関係にあるかを分析する手順である。一次クロス集計によって、 別の要因で二つの下位表に分割して、各表の相関を前述した関係分類等に当てはめる。

\section{3. 調査結果}

\section{1 零次クロス集計結果による要因関連}

危険認知々要因間には、総トン数、自動操舵、在橋人員、乗組員数で有意水準 0.05 以下の相関が認めら れ、時間带も比較的有意水準が高く危険認知の関係について意味的に重要であることから、危険認知の関 連要因を図 1 に示すとおりとした。

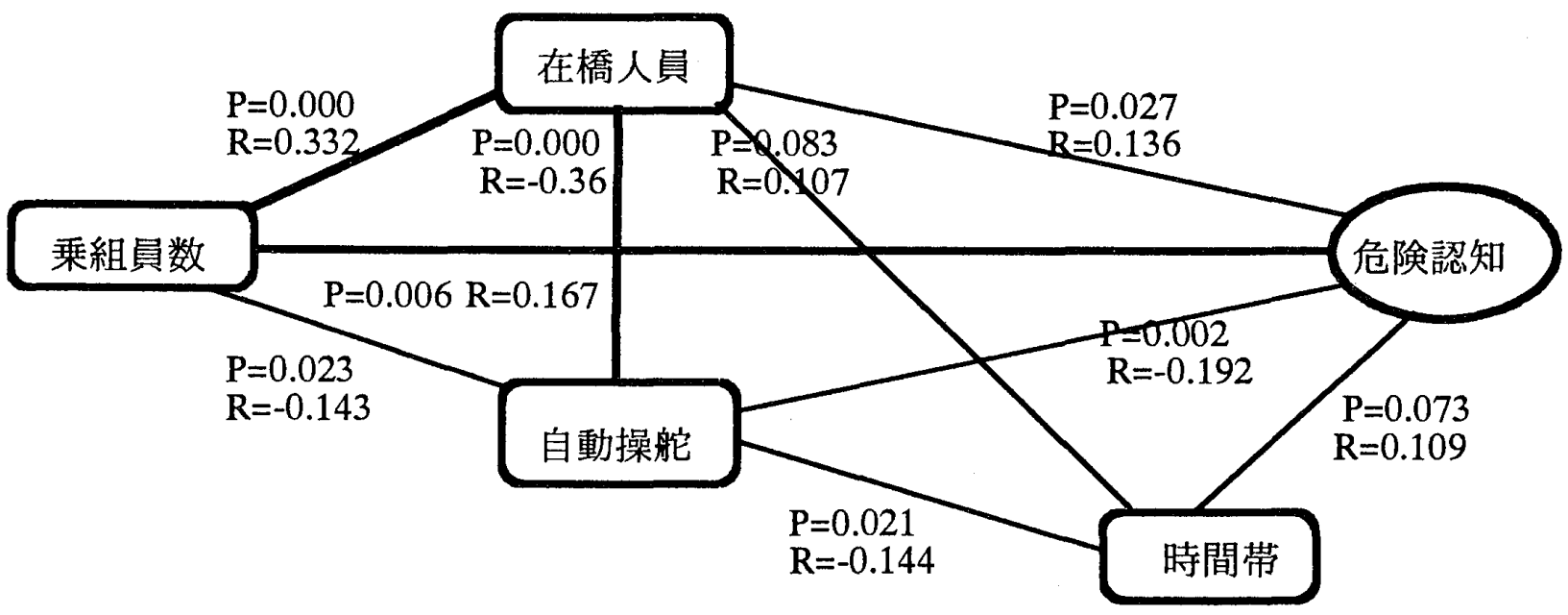

図 1 姴因関連（270サンプル）

注 P : Pearsonのカイ 2 乗漸近有意両側確率

$\mathrm{R}:$ Pearsonの相関係数

\section{2 危険認知亡要因の関係}

危険認知と要因の相関が強いものの順に示す。

図 2 は、零次クロスに第三の要因を加えた二重クロス表の内容を分かり易く示したもので、縦軸を色険 認知無の割合等としてある。零時クロス及び一次クロスにおける要因の傾向をそれぞれの直線の傾きとそ れぞれの直線間の距離によってみることが出来る。

\section{2 .1 危険認知と自動操舵の関係}

(1) 在橋人員の関わり(図 2 における2-1-(1))

在橋人員別の危険認知と自動操舵の相関は、全体の相関 $(\mathrm{R}=-0.192)$ に較べて双方とむ低くなるが、単 独当直で相関が高く $\left(\mathrm{R}^{\prime}=-0.166\right)$ 、複数当直で注低くなる $\left(\mathrm{R}^{\prime \prime}=-0.041\right)$ ことから、在橋人員注「危険認 知一自動操舵」の関係に部分的効果を与えており、単独当直が全体の相関に寄与している。ここで、単独 当直群は複数当直群に較べて自動操舵の使用状況にかかわらず危険認知無の割合が高い。従って、単独 
当直は危険認知無を多くし、しかも自動操舵使用によってその傾向を強化している。

(2) 乗組員数の関わり(図 2 における2-1-(2))

乗組員数が多い群と少ない群に分けたときの「危険認知一自動操舵」の相関は、全体の相関 $(\mathrm{R}=-0.192)$ に較べ、多い群で高 $<\left(\mathrm{R}^{\prime}=-0.230\right)$ 、少ない群で低い $\left(\mathrm{R}^{\prime \prime}=-0.128\right)$ 。従って、乗組員数は 「危険認知一自動操舵」の関係に対し交互効果があり、多乗組員数が全体相関に寄与している。しかし、 少数乗組員群は危険認知無の割合を高めており、全体の相関への寄与と危険認知無の割合の寄与とは反 対の関係にある。

(3) 時間帯の関わり(図 2 における2-1-(3))

夜間、昼間に分けたときの「危険認知一自動操舵」の相関は、全体 $(\mathrm{R}=-0.192)$ に較べ昼間で高く $\left(\mathrm{R}^{\prime}=-0.242\right)$ 、夜間で低い $\left(\mathrm{R}^{\prime \prime}=-0.143\right)$ がそれらは全体の相関 $\mathrm{R}$ 近い値となっている。従って、時間 帯は「危険認知一自動操舵」の関係に対し弱い交互効果があり、比較的昼間の自動操舵不使用が全体の相 関に寄与しており、危険認知無の割合を小さくしている。

3.2 .2 危険認知と乗組員数の関係

(1) 在橋人員の関わり(図 2 における2-2-(1))

乗組員数が多い群と少ない群に分けた「危険認知一乗組員数」の相関は、全体 $(\mathrm{R}=0.167)$ に較べ双方と も低く、単独当直においてほぼ同程度 $\left(\mathrm{R}^{\prime}=0.145\right)$ であるが複数当直で低くなる $\left(\mathrm{R}^{\prime \prime}=0.048\right)$ 。

在橋人員は「危険認知一乗組員数」の関係に対し、部分的な効果があり、単独当直が全体の相関に寄与 している。同時に単独当直群は乗組員数の多少にかかわらず危険認知無の割合を大きくしている。

(2) 自動操舵の関わり(図 2 における2-2-(2))

自動操舵不使用、使用に分けた「危険認知一乗組員数」の相関は、全体 $(\mathrm{R}=0.167)$ に較べ、自動操舵不 使用で高く $\left(\mathrm{R}^{\prime}=0.199\right)$ 、使用で低い $\left(\mathrm{R}^{\prime \prime}=0.093\right)$ 。従って、自動操舵は「危険認知一乗組員数」の関係に 対し交互効果がある。比較的多数乗組群の自動操舵不使用が全体の相関に寄与しており、危険認知無の 割合を小さくしている。

\section{2 .3 危険認知と在橋人員との関係}

(1) 自動操舵の関わり(図 2 に抒ける2-3-(1))

自動操舵不使用、使用に分けた「危険認知一在橋人員」の相関は、全体 $(\mathrm{R}=0.136)$ に較べ双方とも低い $\left(\mathrm{R}^{\prime}=0.089 、 \mathrm{R}^{\prime \prime}=0.115\right)$ が、自動操舵使用で若干高い。しかし、それらの值と全体のRとの差異は少な い。従って、自動操舵は「危険認知一在橋人員」の関係に弱い部分的効果がある。同時に、自動操舵使用 群が危険認知無しの割合を大きくしている。

(2) 乗組員数の関わり(図 2 における2-3-(2))

乗組員数が多い群と少ない群に分けた「危険認知一在橋人員」の相関は、全体 $(\mathrm{R}=0.136)$ に較べ双方と も低くなるが、少数群で高く $\left(\mathrm{R}^{\prime}=0.112\right)$ 、多数群で低い $\left(\mathrm{R}^{\prime \prime}=0.072\right)$ 。しかし、それらの值と全体の $\mathrm{R}$ との差異は少ない。従って、乗組員数は「危険認知一在橋人員」の関係に弱い部分的効果があり、少数群 が全体の相関に寄与している。同時に少数群は危険認知無の割合を高めている。

(3) 時間帯の関わり(図 2 における2-3-(3))

夜間、昼間に分けた「危険認知一在橋人員」の相関は、全体 $(\mathrm{R}=0.136)$ との相関とほぼ同じ $\left(\mathrm{R}^{\prime}=0.136\right.$ 、 $\left.\mathrm{R}^{\prime \prime}=0.116\right)$ である。従って、時間帯は「危険認知一在橋人員」の関係に関わりがない。ただし、夜間は危 険認知無の割合を大きくしている。

3.2 .4 危険認知と時間帯の関係

(1) 自動操舵の関わり(図 2 における2-4-(1))

自動操舵不使用、使用に分けた 危険認知一時間帯」の相関は、全体 $(R=0.109)$ に較べ、自動操舵不使 用で高く $\left(\mathrm{R}^{\prime}=0.144\right)$ 、自動操舵使用で低い $\left(\mathrm{R}^{\prime \prime}=0.040\right)$ 。従って、自動操舵は「危険認知一時間帯」の関 係に交互効果がある。しかし、自動操舵使用は危険認知無の割合を著しく大きくしている。

(2) 在橋人員の関わり(図 2 に抢汀る2-4-(2))

単独当直、複数当直に分けた「危険認知一時間帯」の相関は、全体 $(\mathrm{R}=0.109)$ に較べ、単独当直でほぼ 同程度 $\left(\mathrm{R}^{\prime}=0.108\right)$ であるが、複数当直で低い $\left(\mathrm{R}^{\prime \prime}=0.068\right)$ 。しかし、それらの值と全体の $\mathrm{R}$ ○差異は 少ない。従って、在橋人員は「危険認知一時間带」の関係に弱い部分的効果がある。同時に単独当直は危 
険認知無の割合を大きくしている。

\section{3 要因間の関連}

\section{3 .1 在橋人員と自動操舵の関係}

(1) 乗組員数の関わり(図 2 における3-1-(1))

乗組員数が多い群と少ない群に分けた「在橋人員一自動操舵」の相関は、全体 $(\mathrm{R}=-0.360)$ に較べ、少数 群ではやや弱い相関があり $\left(\mathrm{R}^{\prime}=-0.291\right)$ 、多数群では高い $\left(\mathrm{R}^{\prime \prime}=-0.380\right)$ 。しかし、それらの值の差異は 大きくはない。従って、乗組員数は「在橋人員一自動操舵」に弱い交互効果があり、多数群の寄与が大き い。しかし少数群は単独当直の割合を著しく高めている。
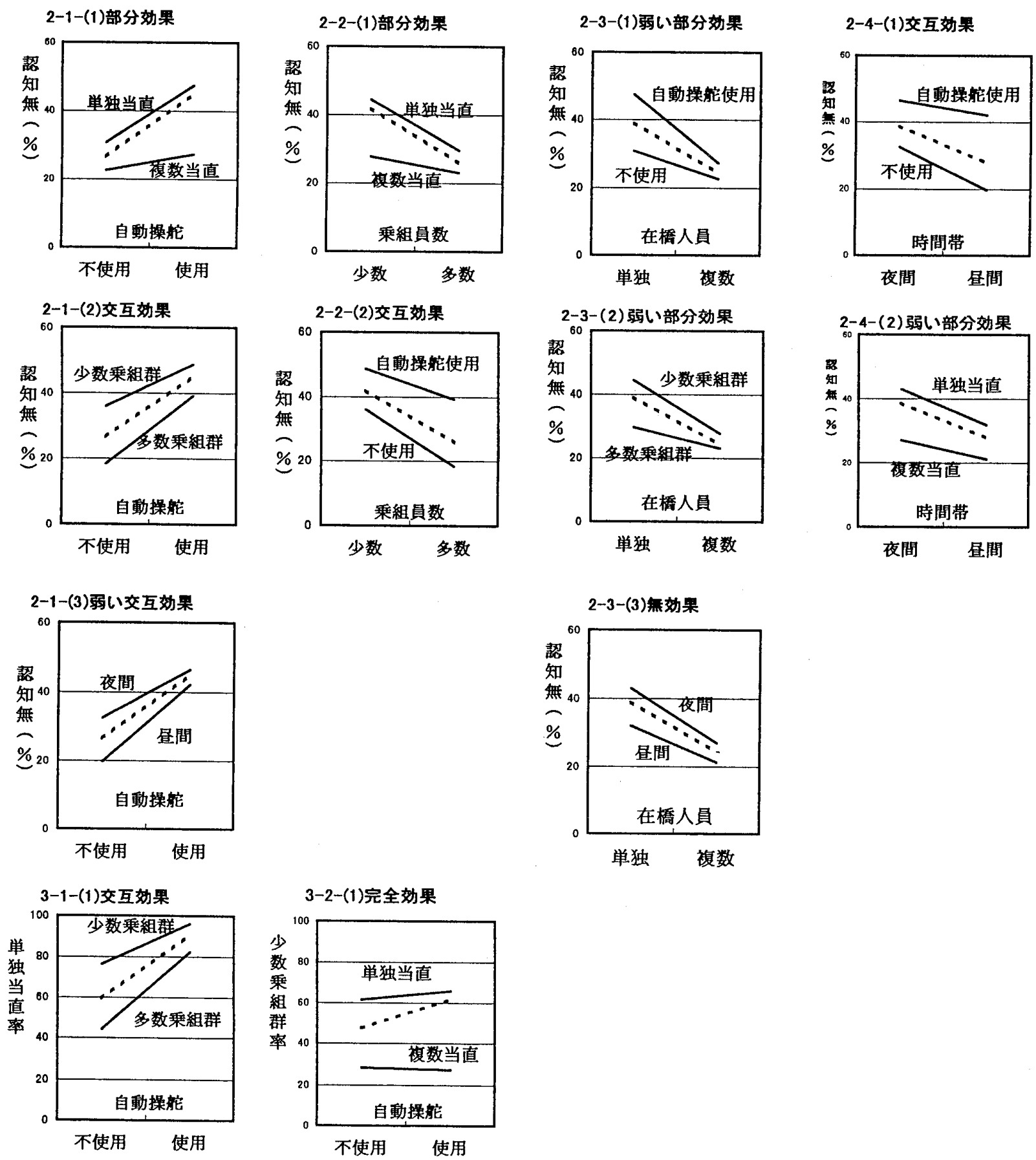

図 2 危険認知等に着目した統制結果

注 点線は全体（零次のクロス表における割合）を示す 


\section{3 .2 乗組員数と自動操舵の関係}

(1) 在橋人員の関わり(図 2 における3-2-(1))

単独当直、複数当直に分けた「乗組員数一自動操舵」の相関は、全体 $\left(\mathrm{R}^{\prime \prime}=-0.143\right)$ に対して、両方とも 著しく低い $\left(\mathrm{R}^{\prime}=-0.043 、 \mathrm{R}^{\prime \prime}=0.009\right)$ 。従って、在橋人員は「乗組員数一自動操舵」の関係に完全な効果 を及ぼしており、「乗組員数一自動操舵」の関係注在橋人数に依存する疑似関係である。そして、単独当 直は乗組員数少数の割合が大きいことと一致している。

\section{4. 考察}

\section{1 海難防止対策への活用}

操船作業は、危険な状況の認知、避航行動の意志決定、操作の段階が順を追って行われる。衝突・乗揚 げ海難は、そのうちのどれかで失敗したときに起こる。初期の段階の失敗、すなわち危険認知無を多くす る要因の関わりを、危険認知が有って起こった事故との対比から分析してきた。自動操舵使用状況、乗組 員数、在橋人員数または時間帯の要因別に危険認知との関連にそれぞれがどの様な関わりをするかを検討 した。このことは、例えば自動操舵使用という条件の時に他の要因がどのように関係するか、そしてその 要因を制御することの意義を明らかにする。前述の調査結果は次のように解釈出来る。

(1) 自動操舵使用時の危険認知ミスに影響する要因

単独当直は自動操舵使用状況、危険認知有無の相関に、また、危険認知ミスの発生率にも強く寄与して いる。乗組員数は多数群でこの相関を強めているが少数群で危険認知ミスを多くしている。時間带では昼 間が相関を強めるているが夜間が認知ミスを多くしている。

ここで、少数乗組員と自動操舵は単独当面に依存する疑似関係であるので無視される。疍間は、認知ミ スが少ない効果を持つので無視出来る。夜間は認知ミズを多くするので無視出来ない。自動操舵と危険認 知ミスの間には単独当直の関与が大きく、時間帯が夜間であることが次いで大きいといえる。

（2）少数乘組員船の危険認知ミスに影響する要因

単独当直は、乗組員数と危険認知の相関に大きく寄与しており、自動操舵使用は完全な効果をもたらし ていることから、少数乗組員が危険認知ミスを多くするのではなく、単独当直と自動操舵がその関係を担 っている。

（3）単独当直時の危険認知ミスに影響する要因

自動操舵使用状況が両者の相関を強化し、使用中が危険認知ミスを多くしている。乗組員数も寄与する が前述の理由で無視出来る。時間帯は両者の相関には寄与しないが、夜間は危険認知ミスを多くしている。 従って、単独当直での危険認知ミスの増大には、自動操舵の関わりが重大で、夜間も寄与している。

(4) 夜間の危険認知ミスに影響する要因

単独当直は泌者の相関の強化にも危険認知ミスの増大にも若干ながら寄与している。自動操舵不使用が 両者の相関を強めるが、使用が認知ミスを増大する。従って夜間には、単独当直が大きな問題で自動操舵 の使用も無視出来ない。

以上の結果から、危険認知ミスの重要な要因関連は、単独当直、自動操舵使用、夜間との間にあるとい える。これら要因の状況の違いによる危険認知ミスの割合から要因の寄与を量ることが出来る。それは在 橋人員数、自動操舵、時間帯で統制した 2 次クロス集計によって可能である。結果は表 2 に示すとおう、 危険認知無の割合が最も大きいのは、サンプルが少ない複数当直・自動操舵使用中を無視すると、単独当

表 2 危険認知・在橋人員・自動操舵・時間带

\begin{tabular}{|c|c|c|c|c|c|c|c|c|}
\hline & \multicolumn{4}{|c|}{ 単独当直 } & \multicolumn{4}{|c|}{ 複数当直 } \\
\hline & \multicolumn{2}{|c|}{ 自動操舵不使用 } & \multicolumn{2}{|c|}{ 首動操舵使用 } & \multicolumn{2}{|c|}{ 自動操舵不使肴 } & \multicolumn{2}{|c|}{ 首動操舵使用 } \\
\hline & 芢闑 & 盒䦧 & 夜閪 & 扈䦓 & 夜堷 & 笪間 & 崔間 & 筸間 \\
\hline 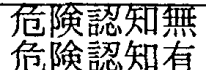 & $\begin{array}{l}36.4 \% \\
63.6 \%\end{array}$ & $\begin{array}{l}23.5 \% \\
76.5 \%\end{array}$ & $\begin{array}{l}49.4 \% \\
50.6 \%\end{array}$ & $\begin{array}{l}42.4 \% \\
57.6 \%\end{array}$ & $28.6 \%$ & $\begin{array}{l}16.0 \% \\
84.0 \%\end{array}$ & $\begin{array}{l}16.7 \% \\
833 \%\end{array}$ & $40.0 \%$ \\
\hline 許、 & $\begin{array}{c}100.0 \\
44\end{array}$ & $100.0 \%$ & $\begin{array}{c}100.0 \% \\
77\end{array}$ & $100.0 \%$ & $100.0 \%$ & $100.0 \%$ & $100.0 \%$ & $100.0 \%$ \\
\hline
\end{tabular}


直・自動操舵使用・夜間で $49.4 \%$ 、単独・使用・昼間で $42.4 \%$ 、単独・不使用・夜間で $36.4 \%$ の順で多く、 他は $20 \%$ 台である。従って、三要因のうちの幾つかの条件を変えることで危険認知ミスを減じる効果を表 2 から推定できる。すなわち、単独当直・自動操舵使用における夜間を昼間と比較すれば僅か減少し、自 動操舵不使用と比較すればかなり減少する。更には、複数当直と比較すれば大幅に減少する。しかし、自 動操舵不使用や複数当直は、別の海難発生に関わる要因の影響が大きい、例えば輻輳海域であるなどの可 能性が考えられ、より正確にこの効果を推定するには、これらの要因を統制した評価が必要になる。

\section{4 多重クロス集計の意義と海難調查のあり方}

前報における、基本集計では調查された要因全体の発生頻度が明らかになり、零次のクロス集計では、 要因間に多くの関連を見ることが出来た。しかし、これらの傾向は、母集団の属性や環境要因分布、例え ば、小型船は少数乗組員であるとか、狭い海域では船長が多いなど、と関係しており状況を説明するに過 ぎないことも多い。一次クロス集計では、設定した第三の要因が関わっているかどうか、関わっている場 合、どのように関わっているかが分かった。

本報告における分析は最も基本的なものであるが、この手法によって、海難防止対策のための対象をよ り明らかにすることが出来ることが分かった。そして、前述したとおり、第三変数そのもの、または第三 変数を有効に制御出来るシステムによって、要因の関連を断つことが海難防止対策となり得ると考えら扎 る。

しかし、解析手法以前によ゙のようなデータを解析するかが大きな問題である。船舶航行については、列 車、自動車、航空機とは違い、航行管制等他からの支援が殆ど無く、当直者によって全てが実施されてい る。しかも、周辺には様々な障害がある。従って、同種海難防止のためには、海難の直接原因 (当直者の不 安全行動、不安全環境)を生み出した背景原因を調查し、そ扎を改善する必要がある。例えば、最小限、次 の調查項目が必要と考えられる。当直者については、勤務状態と休息、心身状態、乗組員の職務分担、運 航スケジュール等が必要であり、交通環境については、交通流、相手船と周辺船舶の動静等が必要である。 そして、勤務や運航の計画、職務の調整、技能向上、航行改善等に役立てる必要がある。

しかし、これらのことが害際の海難で行われるには、海難関係者のかなりの理解が必要である。従って、 比較的取り組み易い方法は、未然事故調査である。筆者らは、この試みをした結果、海難審判における裁 決率、損傷報告率、未然事故報告率がハインリッヒの法則とほぼ同じピラミッド構造をなしていること(7) や、実際の海難との関係が密接であること ${ }^{(8)}$ から、有効な海難事故調查を行う有力な手段といえるものと考 えている。

\section{5.あとがき}

公的な海難調查データから、海難の人的要因に関わる関連を明らかにした。危険認知に直接関連する要 因周辺について、二つの関連要因を他の要因によって統制する一次クロス集計によって、第三の要因の関 わりを調べ、第三の要因を制御すること海難防止対策となり得ることが分かった。

以上の結果は、経験的な海難調查手法によるデータを使用したために、よく知られた関連を定量的に確 認したことになる。海難調查手法を改善することにより、この方法は詳細な海難防止対策に有効となる。

本論は、手法の有効性の確認のためにサンプル全体を対象とした基礎的な多重クロス集計結果について の報告である。サンプル数や有効な調查項目を増やすことにより、高次のクロス集計を行い海難防止対策 のための対象を明らかにすることが出来る。

\section{参 考 文 献}

(1) 運輸省：海上保安白書, 1998 .

(2) IMO: Code for the investigation of marine casualties and incidents IMO Resolution A.849 (20), London 1997.

（3）西島茂市：これからの安全管理p100，中央労働災害防止協会，1996.

(4) 海難審判庁：外国船海難の実態等，1998.

（5）林知己夫：行動計量学序説 (第 2 版)，朝倉書店，p108～122，1996. 
(6) Yoshio MURAYAMA, Yusuke YAMAZAKI and Makoto ENDO: Investigation system for Safety management applying multivate contingency analysis on human errors of maritime casualties, proceeding Qergo'99 International Conference on TQM and Human Factors 1999 in Lincoping Sweden p259 264.

（7） 村山義夫・山崎祐介・遠藤 真(1998）：未然事故調查試行結果について，日本航海学会論文集第98号 $\mathrm{p} 257 \sim 264$.

（8）山崎祐介・村山義夫 - 遠藤 真(1999）：未然事故調查試行結果と事故との比較，日本航海学会論文集 第100号 p245 251.

\section{質 疑 応 答}

斉藤和夫 (海事問題総合研究所)：危険の概念について、保険において「危険」についての定義は種々と問題 を提起している。一般的に、種々の危険事情 (Hazard)のもとに、特定の海難事故 (Perils) が発生し、こ の例えば衝突事故の発生する可能性 (Risk) というように理解されている。論者の考えている「危険の概 念」を教示して下さい。

山崎祐介：本論で設定した危険認知有無という概念は、Riskの認知有無そのものと考えています。従って、 例えば乗揚げ海難の場合、「避航動作無しまたは直前速力が10ノット以上」の場合を危険認知無 (Riskの 認知が無かった）とし、その他の場合を危險認知有としています。 